\title{
BAURAN PEMASARAN PT YAKULT INDONESIAN BERSADA CABANG SINTANG
}

\author{
Felix Semaun \\ Fakultas Ilmu Sosial Politik Universitas Kapuas \\ Alamat Jln .Y.C Oevang Oeray No.92 Sintang, Kalimantan Barat \\ Email: felix.unka@gmail.com
}

\begin{abstract}
Abstrak: Permasalahan dalam penelitian ini adalah Bauran Pemasaran PT Yakult Indonesia Persada Cabang Sintang, Tujuan penelitian ini adalah untuk mengetahui dan mendiskripsikan strategi Bauran pemasaran produk PT Yakult Indonesia Persada Cabang Sintang yang terdiri dari Produk, Harga, Tempat, dan Promosi. Jenis penelitian ini adalah deskriptif dengan subjek penelitian berjumlah 11 orang. Teknik analisis data yang digunakan adalah kualitatif deskriptif yang kemudian dilakukan pembahasan dan dibuat suatu kesimpulan.
\end{abstract}

\section{Kata Kunci : Pemasaran, Produk}

Sehat adalah sebuah kondisi maksimal, baik dari fisik, mental dan sosial sehingga dapat melakukan suatu aktifitas yang menghasilkan sesuatu. Kondisi tubuh yang sehat pada manusia dapat kita lihat dari kebugaran tubuh. Dalam sebuah lingkungan masyarakat terkadang mengalami beberapa masalah kesehatan masyarakat, baik muda, tua, wanita, pria. Dewasan ini banyak produk-produk kesehatan yang berkembang di masyarakat dimana salah satunya adalah produk dari PT Yakult Indonesia Persada.

Kantor Pusat Perusahaan PT Yakult Indonesia PersadaBeralamat Perusahaan di Plaza PP Lt. 7, Jl. TB. Simatupang No. 57 Jakarta 13760, Indonesia. 92 cabang di seluruh Indonesia termasuk Cabang Sintang. Kantor Cabang PT Yakult Indonesia Persada Sintang telah didirikan tahun 2015 yang beralamat di jalan YC Oevang Oeray RT.011,RW.03; Kelurahan Baning Kota,Kecamatan Sintang, Kabupaten Sintang Kalimantan Barat. Dengan daerah operasi Kabupaten Sintang dan Kabupaten Melawi.

Menurut Kotler (2002;17-18) bauran pemasaran dapat diklasifikasikan menjadi 4P (Product, Price, Place, Promotion). Sedangkan menurut Boom dan Bitner yang dikutip oleh Buchari Alma $(2000 ; 234)$ " bauran pemasaran dalam produk jasa perlu ditambah menjadi 3P, sehingga bauran pemasaran jasa menjadi $7 \mathrm{P}$ (product, price, place, promotion, people, physical evidence dan process)." Dalam bauran pemasaran terdapat seperangkat alat pemasaran yang dikenal dengan marketing mix 4P, yaitu product (produk), price (harga), place (tempat atau saluran distribusi), dan promotion (promosi), sedangkan dalam pemasaran jasa memiliki beberapa alat pemasaran tambahan seperti people (orang), physical evidence (fasilitas fisik), dan process (proses), sehingga dikenal dengan marketing mix yakni : product, price, place, promotion, people, physical evidence, dan process. Ketujuh unsur bauran pemasaran tersebut saling berhubungan dan berpengaruh satu sama lain, sehingga harus diupayakan untuk menghasilkan suatu kebijakan pemasaran yang mengarah kepada layanan efektif dan kepuasan konsumen. Jadi di dalam bauran pemasaran terdapat variable-variabel yang saling mendukung satu dengan yang lainnya, yang kemudian oleh perusahaan digabungkan untuk memperoleh tanggapan-tanggapan yang diinginkan di dalam pasar sasaran. Kombinasi dari perangkat tersebut perusahaan dapat mempengaruhi permintaan akan produknya.

Alat bauran pemasaran yang paling mendasar adalah produk, yang merupakan penawaran berwujud perusahaan kepada pasar, yang mencakup kualitas, rancangan, bentuk, merek, dan kemasan produk. Pelayanan pendukung tersebut dapat memberikan keunggulan kompetitif dalam pasar persaingan global.

Adapun ketujuh unsur marketing mix tersebut dapat diuraikan sebagai berikut: Produk ( product), adalah mengelola unsur produk termasuk perencanaan dan pengembangan produk atau jasa yang tepat untuk dipasarkan dengan mengubah produk atau jasa yang ada dengan menambah dan mengambil tindakan yang lain yang mempengaruhi bermacam-macam produk atau jasa.

Harga (price), adalah suatu sistem manajemen perusahaan yang akan menentukan harga dasar yang tepat bagi produk atau jasa dan harus menentukan strategi yang menyangkut potongan harga, pembayaran ongkos angkut dan berbagi variabel yang bersangkutan.

Distribusi (place), yakni memilih dan mengelola saluran perdagangan yang dipakai untuk menyalurkan produk atau jasa dan juga untuk melayani pasar sasaran, serta mengembangkan sistem distribusi untuk pengiriman dan perniagaan produk secara fisik. 
Promosi (promotion), adalah suatu unsur yang digunakan untuk memberitahukan dan membujuk pasar tentang produk atau jasa yang baru pada perusahaan melalui iklan, penjualan pribadi, promosi penjualan, maupun publikasi.

\section{Hasil Dan Pembahasan}

Kegiatan bisnis PT.Yakult Indonesia Persada Cabang Sintang hanya murni kegiatan pemasaran saja, tanpa kegiatan produksi produk. Berdasrkan hasil wawancara dengan pimpinan PT.Yakult Indonesia Persada Cabang Sintang diperoleh keterangan bahwa filosofi Bisnis Produk Yakult yakni "Mencegah lebih baik Dari pada megobati". Usus yang sehat adalah kunci umur panjang.

Produk dalam bentuk barang jadi, yaitu barang yang berupa minuman Kesehatan yang di kenal dengan Yakult. Produk Yakult Merupakan hasil produksi PT Yakult Indonesia Persada yang terdiri dari dua pabrik besar yaitu di Mojokerto dan Sukabumi. PT. Yakult Indonesia Persada mempunyai tagline, Cintai Ususmu Minum Yakut Tiap Hari. Yakult memilih tagline (slogan) ini tentu saja sangat berarti. Keistimewaan Yakult diantaranya : tanpa menggunakan bahan pengawet, tanpa zat pewarna, hanya memiliki satu rasa dan satu warna, dibuat secara higienis, ISO 22000 (tahun 2005), ISO 9001 (tahun 2008), serta mendapatkan pengakuan dari badan POM MUI yang diperbarui setiap 2 tahun sekali.

Yakult memfokuskan diri sebagai minuman kesehatan sehingga sangat memperhatikan kualitas produknya. Masa kadaluarsa Yakult hanya 40 hari sejak diproses dari pabrik. Hal ini membuat produk yanga beredar di pasar adalah produk yang segar dan baik. Yakult hanya bisa disimpan dalam suhu $0^{0}-10^{0}$ Celcius. Yakult mempunyai tiga prinsip, yaitu : mencegah lebih baik dari pada mengobati, usus yang sehat adalah kunci dari kesehatan, dan harga murah.

Produk - produk yang dipasarkan oleh PT. Yakult Indonesia Persada Cabang Sintang dianggap sudah cukup dikenal oleh konsumen dan para konsumen mencintai karena mereka mencintai usus yang sehat berkat meminum yakult secara teratur. Produk yakult sudah tidak diragukan lagi baik Segi kemasan ,Segi merek, segi kualitas, maupun brand image. Namun secara Medical Produk yakult hanya memiliki batas atau masa berlaku selama 40 hari setelah di produksi sehingga produk yakult perlu di pelihara atau disimpan dalam mesin pendingin dengan batas suhu $10^{\circ} \mathrm{C}$. Apabila Masa pemakian produk lewat dari 40 hari maka produk segera harus di tarik dari pasar. Produk yakult dari segi kemasaan amat menarik dan praktis dan ukuranya sesuai dengan takaran medis demikian juga kualitas yakult sudah memiliki nama baik atau di percaya oleh konsumen sebagai suatu produk minuman kesehatan melalui kesehatan usus cintai usus mu demi kesehatan tubuh mu sudah tidak asing lagi bagi kalangan masyarakat.

Produk Yakult sudah standar, dan belum ada keluhan dari konsumen mengenai kelemahan dari produk yang di distribusikan. Sebenarnya permasalahan bukan terletak pada produknya , tetapi lebih banyak terletak pada kemampuan pegawai dalam hal mempromosikan produk sehingga lebih banyak konsumen yang kenal produk dan mengetahui efektifitas dari produk serta harga masing - masing produk yang ada.

Upaya untuk meningkat volume penjualan produk adalah dengan melakukan penawaran langsung kepada calon pelanggan (personal selling) yaitu dengan mendatangi para pemilik toko - toko, super market, mini market, indomaret, alfa mart, baik di kota maupun di daerah pedesaan yang masih memungkinkan untuk dilewati oleh kendaraan roda empat. Selain itu, pihak distributor juga melayani pembelian langsung dari masyarakat sebagai pengguna akhir dari produk tersebut baik dalam jumlah yang banyak maupun sedikit.

PT. Yakult Indonesia Persada Cabang Sintang, menerapkan strategi harga dengan menggunakan sistem kepemimpinan harga rendah (cost leadership strategy). Strategi ini merupakan salah satu strategi pemasaran dari aspek harga yang cukup ampuh untuk melakukan penetrasi pasar yang selanjutnya bertujuan untuk mendapatkan para langganan dan konsumen produk di semua lini di masyarakat.

Strategi kepemimpinan harga rendah, dimaksudkan agar perusahaan dapat menguasai atau memimpin pasar. Harga yang rendah merupakan kunci untuk menarik konsumen, karena konsumen secara umum pasti lebih memilih produk yang lebih murah dengan catatan bahwa kualitas dan nilai manfaat dari produk memenuhi standar yang diinginkan serta tidak kalah dari produk para pesaing.

Tidak hanya proses produksinya, saja yang diperhatikan tetatipi juga menerapkan sistem yang sangat baik dalam jalur pendistribusiannya. Hal ini dilakukan agar kualitas Yakult tetap terjaga dengan baik hingga sampai ke tangan pelanggan. Pimpinan Cabang Sintang menjelaskan bahwa Yakult Indonesia memiliki 2 pabrik yaitu di 
Cicurug-Sukabumi dan di Ngoro-Mojokerto. Dari kedua pabrik ini, Yakult didistribusikan langsung dengan menggunakan truk berpendingin khusus ke 80 cabang Yakult yang berada di hampir seluruh Indonesia.

Di setiap cabang Yakult memiliki tempat penyimpanan Yakult berpendingin khusus pada suhu antara 0 - 10 derajat celcius untuk menjaga kualitas. Yakult didistribusikan langsung melalui sistem Yakult Lady dan Direct Sales. Yakult Lady bertugas mengantarkan Yakult langsung ke tangan pelanggan dengan berkeliling dari rumah ke rumah menggunakan sepeda atau trolley dengan membawa tas khusus dilengkapi es batu atau ice pack. Sedangkan Direct Sales bertugas mengantarkan Yakult ke Supermarket, mini market, toko dan gerai dengan menggunakan mobil khusus berpendingin. Sesampainya di Supermarket atau toko, Yakult langsung dimasukkan ke dalam lemari pendingin khusus. Masa kadaluarsa Yakult adalah 40 hari sejak di produksi dari Pabrik dan tanggal kadaluarsanya dapat dilihat pada pinggang botol atau pada kemasan botol di bagian belakang atas. Dengan menerapkan sistem seperti ini, Yakult yang sampai ke tangan pelanggan adalah Yakult dengan kualitas yang baik.

Aspek tempat merupakan aspek ketiga dari strategi pemasaran di dalam bauran pemasaran (marketing mix). Tempat dalam perspektif pemasaran adalah suatu wadah dimana dilaksanakannya proses pemasaran. Proses pemasaran termasuk di dalamnya adalah kegiatan pengemasan, penyimpanan, dan pencatatan barang - barang yang diperoleh, di simpan digudang, dan selanjutnya dilakukan pendistribusian (pengantaran produk) ke para pelangganan yang melakukan pemesanan. Oleh sebab itu aspek tempat memegang peranan penting yang harus dikaji dengan matang oleh para pelaku usaha bisnis, termasuk perusahaan PT. Yakult Indonesia Persada Cabang Sintang.

PT. Yakult Indonesia Persada Cabang Sintang. memiliki kantor cabang yang di lengkapi dengan mesin pendingin khusus / penampungan barang letaknya cukup strategis berada di Jalan Oevang Oeray Desa Baning Kota Kabupaten Sintang. Sebagai pusat pengendali bisnis pendistribusian produk PT. Yakult Indonesia Persada Cabang Sintang. memiliki sebuah kantor dan gudang, serta halaman yang cukup luas untuk parkir kendaraan perusahaan.

Perencanaan sesuai tugas pokok dan fungsi masing-masing. Bagi manager level teratas tentu membuat perencanaan yang menyeluruh yang bersifat umum, termasuk di dalamnya adalah perencanaan tentang operasional penjualan, pembuatan strategi-strategi di dalam usaha pemasaran, pembuatan peraturan -peraturan, baik peraturan tentang karyawan maupun peraturan yang yang berkaitan dengan ketentuan mengenai sistem dan prosedur pemasaran.

Pada dsarnya kantor cabang merupakan distibutor pabrik PT. Yakult Indonesia Persada untuk menyalurkan produk yakult ke pihak pelanggan atau konsumen. Sistem distribusi yakult dapat digambarkan pada gambar 1 berikut :

Gambar 1. Saluran Distribusi Produk

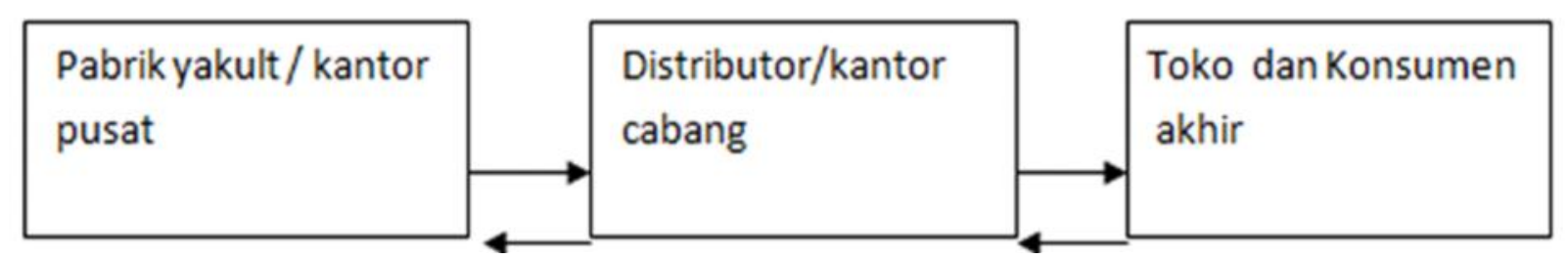

Sumber: kantor PT. Yakult Indonesia Persada Cabang Sintang 2019

Berdasarkan gambar tersebut dapat dijelaskan bahwa Arus barang dari pabrik hingga konsumen dengan tanda panah daari kiri ke kanan. Arus uang dari konsumen kembali ke pabrik dengan tanda panah dari kanan ke kiri. Sistem pendistribusian barang / produk yakult sejak dari pabrik hingga konsumen pada dasarnya cukup lancar . namun masih kendala dalam hal transportasi dari kota ke desa-desa kurang di dukung oleh perasarana jalan yang kurang memadai. Sedangkan aliran arus uang dari konsumen menuju kembali ke pabrik relatif lancar. Karena penetapan harga terjangkau oleh konsumen dan produk yakult amat bermanfaat bagi kesehatan tubuh melalui kesehatan usus .

Strategi promosi yang di lakukan nya terdiri dari promosi melalui periklanan, promosi 
penjualan, Hubungan masayarakat dan Penjualan pribadi. Yakult Mengiklankan produknya menggunakan media elektronik seperti TV dan radio, Media cetak seperti majalah dan koran, serta internet dengan situs resminya yaitu www.yakult.co.id , serta melalui berbagai media sosial seperti facebook, twitter, dan kaskus. Namun, tentu saja masyarakat paling mengingat produk yakult berkat iklannya di TV. Yakult mempunyai tagline, "Cintai Ususmu Minum Yakut Tiap Hari”. Ketika masyarakat mendengar tagline ini di TV, tagline tersebut langsung memberikan masyarakat pesan dan kesan jika meminum yakult setiap hari akan membuat usus kita sehat dan membuat yakult menjadi produk yang wajib dikonsumsi oleh masyarakat setiap hari. Yakult memiih tagline ini tentu saja sangat berarti. Cintai usus adalah cara baru untuk peduli terhadap diri sendiri. Usus adalah organ tubuh yang penting agar tubuh menjadi bugar, kuat, dan segar. Jika usus kita baik maka kitapun bisa hidup dengan baik pula.

Yakult juga pernah memberikan promo harga di warung dan supermarket dengan 'beli 5 gratis 1 ". Yakult Lady pun akan memberikan harga yang lebih murah dibandingkan dengan harga di warung ketika mereka berkunjung ke rumah-rumah warga.

PT Yakult membangun hubungan masyarakat yang baik melalui sistem distribusi Yakult Lady. Sistem distribusi Yakult Lady yaitu sistem pendistribusian Yakult oleh ibu-ibu rumah tangga kepada masyarakat di lingkungan tempat tinggal mereka. Ketika melayani masyarakat, Yakult Lady memberikan informasi kesehatan kepada pelanggan, sehingga Yakult Lady disebut pula sebagai "Pusat Informasi Berjalan".

Para sales Yakult ini memiliki wilayah pemasaran yang tetap sehingga bisa mendorong keakraban yang berlanjut antara sales dengan para konsumen. Beberapa sales yang komunikatif dan luwes bahkan merasa memiliki banyak teman dan kerabat baru yang didapatkan selama mereka bertugas. Keterampilan berkomunikasi akan menjadi modal utama bagi para sales ini dalam meningkatkan target penjualannya.

Yakult Lady yang secara tidak langsung juga bertugas mengampanyekan program kunjungan pabrik. Program kunjungan ke pabrik yakult membuat pengunjung dapat melihat secara langsung proses produksi Yakult. Tenaga sales yang rata-rata ibu rumah tangga mungkin lebih menarik simpati dan membuat para calon konsumen tak tega untuk menolaknya. Berbeda dengan sales produk produk otomotif yang lebih menonjolkan penampilan fisik, para sales yakult adalah ibu-ibu yang rata-rata berusia 30 - 50 tahun, namun penampilan fisiknya sangat bersahaja dan menawarkan keramahan dan kehangatan yang mungkin tidak bisa kita dapatkan saat berbelanja di pasar swalayan. Strategi pendekatan sisi kemanusiaan yang tengah ditawarkan produsen Yakult ini tampaknya cocok dengan karakteristik masyarakat Indonesia yang masih sangat erat memegang teguh nilai- nilai kekeluargaan.

Kesimpulan Yakult mempunyai tagline, “Cintai Ususmu Minum Yakut Tiap Hari”. Ketika masyarakat mendengar tagline ini di TV, tagline tersebut langsung memberikan masyarakat pesan dan kesan jika meminum yakult setiap hari akan membuat usus kita sehat dan membuat yakult menjadi produk yang wajib dikonsumsi oleh masyarakat setiap hari. Para sales yakult adalah ibu-ibu berusia 30 - 50 tahun yang penampilan fisiknya sangat bersahaja dan menawarkan keramahan dan kehangatan yang mungkin tidak bisa kita dapatkan saat berbelanja di pasar swalayan. Ketika melayani masyarakat, para sales ini akan memberikan informasi kesehatan kepada pelanggan. Para sales Yakult ini akan memberikan harga Yakult yang lebih murah dibandingkan dengan harga di warung maupun supermarket.

Pengaruh dari kegiatan promosi sangat besar terhadap volume permintaan produk oleh konsumen. Melalui promosi konsumen menjadi tahu, setelah itu mereka merasa tertarik untuk membeli, ada yang sekedar ingin coba - coba untuk suatu produk yang baru, dan ada juga yang membeli suatu produk karena berdasarkan manfaat dari produk.

Pengaruh terhadap permintaan produk di suatu agen, distributor dan toko pengecer secara tidak langsung dipengaruhi kegiatan promosi tentang produk PT. Yakult Indonesia Persada Cabang Sintang di berbagai tempat yang dilakukan oleh unit bisnis secara keseluruhan. Dengan demikian tingkat permintaan suatu produk di PT. Yakult Indonesia Persada Cabang Sintang bukan saja dipengaruhi oleh promosi yang dilaksanakan oleh perusahaan secara mandiri tetapi sedikit banyak dipengaruhi oleh bauran promosi yang dilaksanakan oleh lembaga bisnis yang lain di seluruh Indonesia.

Promosi melalui iklan dengan media elektronik yang marak sekarang ini adalah promosi 
produk lewat internet.. Pemesanan dan pembelian produk tidak tatap muka, tetapi melalui komunikasi jarak jauh menggunakan telepon dan media sosial yang banyak sekali jenisnya. Sistem iklan melalui media elektronik lebih efektif, karena di jaman sekarang rata - rata masyarakat dapat menonton televisi dan hampir disemua daerah internet dapat diakses, dengan demikian masyarakat dengan mudah dapat melihat promosi - promosi yang ditampilkan. .

Promosi selanjutnya adalah melalui media seperti baleho dan spanduk - spanduk yang dipajang di tempat - tempat strategis diperkotaan, sering kita lihat baleho dengan ukuran besar tentang produk di pasang di tempat - tempat keramaian seperti di pusat pembelanjaan dan jalan raya. Promosi dengan menggunakan media spanduk dan baleho .

Promosi berikutnya adalah publisitas, yaitu dengan memberitahukan kepada masyarakat tentang produk - produk dengan melakukan event - event, seperti pameran produk, dan menonton film showing yakult dalam sebuah event, misalnya pameran yang ditampilkan dalam acara pekan raya pemerintah daerah kabupaten, pasar malam, dan sebagainya. Publisitas juga dapat melalui media surat kabar dan media elektronik tentang peluncuran suatu produk yang baru.

Bauran promosi selanjutnya adalah dengan melakukan penjualan pribadi langsung (personal selling). Cara ini dianggap juga cukup ampuh untuk memperkenalkan dan menumbuhkan minat konsumen untuk membeli produk. Penjualan pribadi dilakukan dengan berbagai cara yaitu dengan mendatangi langsung konsumen ke rumah - rumah (door to door), melalui surat (mail order), dan bisa melalui telepon (telephone selling).

Promosi yang dilaksanakan oleh PT. Yakult Indonesia Persada Cabang Sintang lebih di fokuskan pada personal selling karena berinteraksi langsung dengan para pelanggan. Cara ini dapat dilakukan sambil melakukan pengantaran produk ke toko - toko yang sudah menjadi langganan. Selain itu bentuk promosi penjualan, seperti pemberian discount, bonus, dan hadiah juga dilakukan oleh PT. Yakult Indonesia Persada Cabang Sintang. Pemasangan iklan dan publisitas tidak dilakukan, mengingat jenis promosi ini sudah dilakukan secara terintegrasi oleh PT. yakult indoneisa persada pusat. Berkat kombinasi bauran pemasaran (Marketing mix) yang saling terpaut dan tergantung antara bauran pemasaran yang satu dengan yang lainya mulai dari strategi produk, stretegi harga ,strategi distribusi /tempat, dan strategi promosi berdampak atau berpengaruh langsung terhadap pencapaian target pada omset penjualan produk PT. Yakult Indonesia Persada Cabang Sintang. Sebagaimana diketahui pada tabel 4.6 bahwa volume penjualan produk yakult berdasarkan satuan/unit /botol mencapai angka Target = 6.120.000 Botol dan capaian target $/$ realisasi $=$ 6.147.000 Botol. Sementara nilai nominal hasil penjualan pada tabel 4.7 diketahui target $=\mathrm{Rp}$ 9.914.400.000 dan capaian target $/$ realisasi $=\mathrm{Rp}$ 9.958.140.000 atau dengan tingkat pencapain target $100,99 \%$.

\section{Kesimpulan Dan Sarana}

Strategi produk (Product), Merupakan minuman Kesehatan yang di kenal dengan yakult. PT Yakult Indonesia Persada Cabang Sintang mempunyai tagline, Cintai Ususmu Minum Yakut Tiap Hari. Keistimewaan Yakult diantaranya : tanpa menggunakan bahan pengawet, tanpa zat pewarna, hanya memiliki satu rasa dan satu warna, dibuat secara higienis, ISO 22000 (tahun 2005), ISO 9001 (tahun 2008), serta mendapatkan pengakuan dari badan POM MUI yang diperbarui setiap 2 tahun sekali Produk yakult Merupakan hasil produksi PT Yakult indonesia persada yang terdiri dari dua pabrik besar yaitu di Mojokerto dan Sukabumi. Strategi harga (Price) penetapan harga Produk berdasarkan beberapa pertimbanagan : faktor daya beli, faktor biaya, faktor keuntungan dan faktor manfaat bagi pelanggan. Atas dasar pertimbangan tersebut maka penetapan harga yang dilakukan PT Yakult Indonesia Persada Cabang Sintang terdiri dari harga tunai dan harga non tunai atau harga kredit. Harga tunai / kontan sebesar Rp. 1.620,00 perbotol, sedangkan harga kredit adalah harga diskon khusus untuk alfamart sebagai harga promosi sebear Rp. 1.616,00. Strategi harga berpengaruh langsung terhadap pencapaiaan target penjualan produk PT Yakult Indonesia Persada Cabang Sintang Strategi Distribusi / tempat (Place) Yakult Indonesia memiliki 2 pabrik yaitu di CicurugSukabumi dan di Ngoro-Mojokerto. Dari kedua 
pabrik ini, Yakult didistribusikan langsung dengan menggunakan truk berpendingin khusus ke 80 cabang Yakult yang berada di hampir seluruh Indonesia. Di setiap cabang Yakult memiliki tempat penyimpanan Yakult berpendingin khusus pada suhu antara $0-10$ derajat celcius untuk menjaga kualitas didistribusikan langsung melalui sistem Yakult Lady dan Direct Sales bertugas mengantarkan Yakult ke Supermarket, mini market, toko dan gerai dengan menggunakan mobil khusus berpendingin. Sesampainya di Supermarket atau toko, Yakult langsung dimasukkan ke dalam lemari pendingin Masa kadaluarsa Yakult adalah 40 hari sejak di produksi dari Pabrik dan tanggal kadaluarsanya dapat dilihat pada pinggang botol atau pada kemasan 5 botol di bagian belakang atas. Sistem distribusi dari pusat pabrik ke kantor cabang kemudaian di lanjutkan ke toko/ Super market,Mini Market, Alfamart, Indomaret hingga ke konsumen akhir merupakan sistem distribusi yang terpusat sejak dari kantor pusat hingga ke kantor cabang yang berpengaruh langsung terhadap kelancaran penyampaian barang / produk dari pabrik hingga konsumen akhir.

Strategi promosi ( Promotion), PT.Yakult Indonesia Persada Cabang Sintang secara umum menerapan strategi bauran promosi (promotion mix), yaitu periklanan, promosi penjualan, publisitas, dan penjualan pribadi. Ke empat cara promosi ini saling melengkapi dan menguatkan sehingga produk PT.Yakult Indonesia Persada Cabang Sintang dikenal baik oleh masyarakat.

Sebaiknya pihak PT.Yakult Indonesia Persada Cabang Sintang dapat meningkatkan penjualan produk, trutama yakult lady sehingga konsumen dapat dengan mudah memperoleh produk.Sebaiknya dari segi harga dapat dipertahankan harga rendah dengan tetap memperhitungan efisiensi usaha. Sebaiknya tempat PT.Yakult Indonesia Persada Cabang Sintang terletak lebih terbuka, didepan jalan utama sehingga mudah dilihat dan diketahui masyarakat umum dan tingkat kan jumlah mobil boxs khusus yakult agar pengiriman barang ke toko-toko lebih cepat sampai di tangan konsumen. Sebaiknya Kegiatan promosi penjualan sebaiknya lebih diintensifkan, terutama mengenai manfaat dan keunggulan produk, sehingga masyarakat semakin banyak sehatn dan tahu dengan produk yakult dengan demikian permintaan konsumen akan produk dapat meningkat.

\section{Daftar Pustaka}

Alma, B. 2005. Kewirausahaan. Bandung : Alfabeta.
Arikunto, S. 1998. Prosedur Penelitian. Jakarta : Rineka Cipta.

Buchari Alma. 2007. Manajemen Pemasaran \& Pemasaran Jasa, Bandung: CV. Alfabeta.

Departemen Pendidikan Nasional. 2001. Kamus Bahasa Indonesia Edisi Ketiga. Jakarta : Balai Pustaka.

Faisal, S. 2001. Format-Format Penelitian Sosial. Jakarta : PT. Raja Grafindo persada.

Gitosudarmo, H. 2001. Manajemen Strategis. Yogyakarta : PT. BPFE.

Gitosudarmo, H. 2001. Prilaku Keorganisasian. Cetakan Ketiga, Jogyakarta : BPFE.

Hurriyati. 2008. Bauran Pemasaran dan Loyalitas Konsumen. Bandung : Alfabeta.

Juran. 2004. Merancang Mutu, Ancaman Baru Mewujudkan Mutu Ke dalam Barang dan Jasa. Jakarta : Pustaka Binaan Pressindo.

Kotler, P dan Keller. 2009. Manajemen Pemasaran. Jilid 1 Jakarta: PT. Gramedia Pustaka Utama.

Kotler, P, 2007. Manajemen Pemasaran, edisi 11 jilid 1. PT. Gramedia Pustaka Utama, Jakarta.

Molan, B. 2007. Manajemen Pemasaran. Edisi Keduabelas, Jilid 1. Jakarta : PT. Indeks.

Moleong, L.J. 2000. Metodologi penelitian kualitatif. Bandung : PT. Remaja Rosdakaya.

Nasir, M. 1988. Metode Penelitian. Jakarta : Ghalia.

Nasution, M. 2004. Manajemen Jasa Terpadu.

Bogor : Ghalia Indonesia.

Nasution, S. 2001. Metode Penelitian Naturalistik Kualitatif. Bandung: PT. Remaja Rodakarya.

Nawawi, H. 1995. Metedologi Penelitian. Yogjakarta: Gadjah Mada University Press. 1995. Metode Penelitian di Bidang Sosial. Cet. 9. Yogyakarta : Gadjah Mada University Press.

Ratih, H. 2008, Manajemen Corporate dan Strategi Pemasaran Jasa Pendidikan. Bandung: Alfabeta.

Saladin, D, 2007. Manajemen Pemasaran. Bandung: Linda Karya.

Singarimbun dan Effendi. 1989. Metode Penelitian Survey. Yakarta: LP3ES.

Tandjung, W. 2004. Marketing Management : Pendekatan Pada Nilai-nilai Pelanggan. Edisi Kedua, Cetakan Kedua. Malang : Bayumedia Publishing,.

Triana, A. 1985. Menerapkan Strategi Marketing Di Indonesia. Jakarta : Marketing Seminars 